\title{
GATUNKOWE UWARUNKOWANIA ZNACZEŃ SYMBOLICZNYCH
}

Słowa klucze: znaczenia symboliczne, gatunek, folklor, wartości Keywords: symbolic meaning, genre, folklore, values

Folklor jako ustna twórczość słowna i jego swoisty język poetycki funkcjonuje na dwu poziomach:

[...] wewnątrz kultury ludowej jako jej ważny składnik powiązany z tradycyjnymi wierzeniami i ludową obrzędowością oraz w ramach ponadregionalnej kultury narodowej jako sprawdzony punkt odniesienia, niekiedy miernik dokonań literackich, często - źródło inspiracji (Bartmiński 1993: 213).

Na takich też poziomach - wewnątrz i zewnątrz kultury ludowej - funkcjonują poszczególne słowa, takie jak lipa, łąka, ogród, które mogą być rozumiane „po literacku” albo „po ludowemu”:

(1) Stoji mi lipeńka, stoji mi zielona. A pod tą lipeńką biały kamień leży. Spod tego kamienia bystra woda bieży. A w tej to wodeńce Maryja się myła, a jak się umyła, Syna porodziła.

(2) Mam ci ja Jasiu łączkę zieloną, na niéj traweczkę niepokoszoną. Tylko koszenia potrzeba, da nam Pan Bóg wszystko z nieba, dobrze nam będzie.

(3) Po cóżeś mi w ogródeczek wjechał, powiedziałeś, że mnie będziesz kochał.

Na gruncie ogólnonarodowym przytoczone teksty i słowa w nich użyte mogą być odczytywane dosłownie: lipa jest drzewem o szerokiej koronie, sercowatych liściach 
i miododajnych, wonnych kwiatach, koszenie łąki łączone bywa z pracą rolniczą, polegającą na ścinaniu trawy, a wjechanie $w$ ogródek - z wyrządzoną komuś szkodą. W systemie znaków kultury ludowej tym samym motywom i słowom - poza wskazanymi wyżej znaczeniami - przypisywane są też sensy naddane. Używając formuły Jurija Łotmana, można powiedzieć, że „idee pewnej treści” służą tu jako plan wyrażenia dla treści innej, z reguły kulturowo cenniejszej (Łotman 1988: 151). Łąka i ogródek w pieśniach miłosnych i zalotnych przyjmują znaczenia przestrzeni pozostającej w gestii panny, a koszenie łąki i wjechanie w ogródek są rozpoznawalne jako symboliczne przedstawienie aktu miłosnego.

Słownik drugiego stopnia, słownik znaczeń naddanych - jak to ujęła Maria Renata Mayenowa w Poetyce teoretycznej (1974) - jaki nadbudowuje się nad znaczeniami dosłownymi, jest derywowany z ,naturalnych znaków rzeczy” i zrozumiały jedynie w ramach określonego kodu kulturowego (por. Tołstoj 1995; Tołstaja 2008), akceptowanego przez daną wspólnotę komunikacyjną. Do prawidłowego odczytania znaczeń naddanych, symbolicznych, niezbędny jest właściwy kontekst, który pozwoli przypomnieć i odkodować sensy, wyrażone zapomnianym językiem symboli (por. Fromm 1972). Odszyfrowywanie znaczeń możliwe jest między innymi dzięki „dekoderom” językowym: systemowym (etymologii, znaczeniom metaforycznym) i tekstowym (paralelizmom, ekwiwalencjom międzytekstowym), może też wynikać z ogólnych konwencji gatunkowych oraz danych „przyjęzykowych”, tj. wierzeń i praktyk (por. Niebrzegowska-Bartmińska 2013).

W tym miejscu skupię uwagę przede wszystkim na konwencjach gatunkowych tekstu, które - moim zdaniem - w decydującym stopniu wpływają na kierunek symbolicznych interpretacji.

Puntem wyjścia są stwierdzenia Aleksandra Potebni (2007: 8-9):

1) że symbolika pozostaje $w$ ścisłym związku $z$ językiem

(„только с точки зрения языка можно привести символы в порядок, согласный с воззрениями народа");

2) że symbolika częściej występuje w starych gatunkach tekstu niż nowszych („Так как символизм есть остатек незапамятной старины, то встретить его можно преимущественно там, где медленнее происходит отделение мысли од языка, куда медленнее проникат новое");

3) że symbolika częściej funkcjonuje w pieśniach kobiecych niż w męskich, a w każdym z tych typów pieśni jest jakościowo różna

(„[...] связ с языком и символизмом, характеризующие женские песни, встречаются в мужских в гораздо меншей степени; мысль мужчины шире, подвижнее, изменчивее в силу новых входящих в нее стихийий, чем мысль женщины, заключенной в кругу медленно изменяющегося домошнего быта, более близкой к природе и неподвижному разнообразию явлений”). 
Twierdzę, że obecność symboli w folklorze łączy się nie tyle $\mathrm{z}$ wiekiem tekstów i całych gatunków (w starszych miałoby symboliki być więcej niż w nowszych), nie tyle z rodzajem wykonawców (w pieśniach kobiecych symbolika częstsza niż męskich), co przede wszystkim ze specyfiką gatunkową tekstów. Na tę specyfikę składa się zawarty w gatunku obraz świata, postacie działające, ich atrybuty, przyjęta koncepcja przestrzeni i czasu oraz ogólna idea, która organizuje tekst jako makroznak. Owa idea odpowiada światu wartości, który zdaniem kognitywistów (zob. Krzeszowski 1994; Bartmiński 2003) leży u podłoża obrazu świata. Idąc dalej tym tropem, można też przyjąć, że symbolika zawarta w gatunku tekstu pozostaje w ścisłym związku z systemem wartości (Niebrzegowska-Bartmińska 2015).

Nie kwestionując generalnie ustaleń ukraińskiego badacza, z perspektywy ponad wieku od ukazania się jego prac na temat symboliki (Potebnia 1883-1887: 6165), należy dopowiedzieć, że nawet gatunki uznawane za archaiczne, jak zagadka czy zamówienie, podlegają znaczącym modyfikacjom i obok na przykład zagadek przekazujących tradycyjny obraz świata pojawiają się też teksty o nowszych artefaktach. Przykładowo, poza zagadkami, które odwołują się do animistycznego widzenia przyrody, jak Siwy wół wypił wody dół <Mróz> (Folf Zag nr 139); Czarna krowa popod niebem lata <Chmura> (Folf Zag nr 102), funkcjonują też nowsze': Co to za swinia, że kiéj ję sę w Gduńsku za ogón krący, to w Warszawie je czëc jéj kwiczenié? $<$ Telefon> (Folf Zag nr 125) i Sapie jak wilk, nëkô jak wiater, a ze tba mu sę kurzy <Lokomotywa> (Folf Zag nr 133); Owsa ni jada, ni stoji w uborzy, za dziesięć koni ziemi zaorze < Traktor $>$ (TN 93B Huta 1966).

Podobną modyfikację w zakresie obrazu świata, choć być może nie w takim samym stopniu jak zagadki, przechodzą tradycyjne zamówienia znachorskie, które bywają przekształcane dla nowych potrzeb i wykorzystywane jako podstawa tworzenia form uwspółcześnionych treściowo, służących na przykład naprawie uszkodzenia komputera (dokumentuje je Zuzanna Grębecka, autorka książki Słowo magiczne poddane technologii (2006)):

Wstanę ja, włączywszy się, pójdę zresetowawszy się ze ścieżki dostępu na ścieżkę dostępu, z folderu do folderu. Pod menu, pod pasek narzędzi, na monitor, na ekran. A z monitorem-ekranem ramię w ramię stoi hardware, płyta główna. A ty hardwarze, płyto główna - wyrzuć z pentium mojego (procesor) porczę systemową i porczę BIOS-a, uwolnij od niej makra, wyrzuć to do najnowszej wersji programu antywirusowego, przetestuj i ulecz, jeśli spowodowała jakieś uszkodzenia, żeby nie mogła ani wejść, ani wyjść (Grębecka 2006: 221; on-line: http:/sirota.narod.ru/here.thm, dostęp: 10 III 2003).

Komentarza krytycznego wymaga też podział na pieśni męskie i żeńskie oraz zróżnicowanie symboliki w obydwu typach gatunkowych. W folklorystyce polskiej

1 Jedne i drugie rejestrują Sławomir Folfasiński w zbiorze Polskie zagadki ludowe (Folf Zag) oraz lubelscy autorzy w monografii na temat zwierząt w polskiej kulturze ludowej (Bart Wąż). 
klasyfikacja, o której mówi A. Potebnia, przyjęła się za sprawą Wacława z Oleska (Wacława Michała Zaleskiego), autora zbioru Pieśni polskie i ruskie ludu galicyjskiego (1833, zob. PPiR), który za „najstosowniejszą” zasadę wyodrębniania pieśni uznał - za Vukiem Karadżiciem - podział na: a) pieśni żeńskie, tj. pieśni śpiewane w czasie uroczystości, w czasie obrzędów (np. weselnych), zabaw (np. tańce), pieśni miłosne, rolnicze, pasterskie, myśliwskie, flisackie, górnicze, wojackie, oraz b) pieśni męskie (historyczne i dotyczące pojedynczych osób). Zdaniem współczesnych badaczy podział ten lepiej jest interpretować jako wyróżnienie: utworów o charakterze lirycznym (pieśni żeńskie) i tekstów o charakterze epickim (pieśni męskie) (Adamowski, Bartmiński 1988: 54).

Monograficzne opracowania pieśni ludowych (z Kujaw, Kaszub, Lubelskiego, Warmii i Mazur, Podlasia) pokazują, że kryterium wykonawcy w nowszym folklorze uległo wyraźnemu rozmyciu - poświadczone jest wykonywanie kołysanek przez mężczyzn ${ }^{2}$ i widowisk kolędniczych, niegdyś typowo męskich, jak Herody przez kobiety ${ }^{3}$. Dochodzi również do zamiennego wykonywania tekstów kolęd dla kawalera i dla panny przez wykonawców męskich i żeńskich. Podział pieśni na męskie i żeńskie stracił zatem swoje uzasadnienie. Z punktu widzenia opisu symboliki w tekście pieśni miłosnej, bajki, ballady itp. ważniejszy niż wykonawca i adresat zewnątrztekstowy jest temat i podmiot wpisany w tekst. W pieśniach, których tematem jest np. miłość (zob. Bartmiński 1974; Prorok 2014), podmiotem wewnątrztekstowym może być:

a) dziewczyna („ona”): Ja w fartuszku gruszki mam, kogo kocham temu dam, kalina, dziewczyna, kalina moja, Kogo kocham, temu dam (Bart PANLub nr 2979A); b) chłopak („on”): Szumiała dąbrowa, jakżem przez nia jechał, płakała dziewczyna, żem jej nie poczekał (Bart PANLub nr 2996C);

c) jak też nieokreślony subiekt wpisany w tekst - ktoś, kto kochanków postrzega niejako z zewnątrz. Jerzy Bartmiński (1974) określił go mianem „nadrzędnej świadomości”, „hiperpodmiotu”: Z tamtyj strony jeziora pasła panna gusiora (Bart PANLub nr 2982B).

Przechodząc do właściwego tematu, zaprezentuję obrazy JABŁONI i JABŁKA, tj. dwie wybrane jednostki słownika języka ogólnego o utrwalonych znaczeniach podstawowych, które przyjmują sensy naddane na wyższym poziomie semantycznym, stają się signifiant dla nowego znaku.

Jabłon to w ISJP 'drzewo owocowe, na którym rosną jabłka', a jabłko to 'kulisty, jadalny owoc o cienkiej czerwonej, zielonej lub żółtej skórce i białym lub żółtawym miąższu z małymi, brązowymi pestkami w środku' (ISJP I: 552).

2 W monografii Lubelskie rejestrujemy bogaty repertuar kołysanek od Feliksa Wagi z Zawady koło Zamościa (Bart PANLub 3: 7-60).

3 Przypadek taki zapisaliśmy w Woli Batorskiej pod Krakowem. Nie są to jednostkowe przykłady zjawiska. 
W tekstach folkloru (w zależności od gatunku) obrazy JABŁONı i JABŁKa przyjmują sensy dodatkowe, symboliczne: płodności, urody, młodości, miłości, życiodajnych mocy, dobrobytu i bogactwa, władzy i panowania nad światem, zdrowia, mediacyjności (Ogrod Zwycz: 67; Kow Lek: 169-172)4.

W pieśniach weselnych obraz jabłoneczki, która sadzi dziewczyna, jabłoneczki, która rośnie, kwitnie, rozwija się, dojrzewa i wydaje owoce, która pozbawiona jest kwiecia lub jabłek, daje się wykładać na tle symboliki etapów obrzędu weselnego, rytualnych działań oraz postaci i atrybutu przedmiotowego nazywanego jabłoneczką.

W obrzędowo-rytualnym kontekście mianem jabłoneczki określana była na przykład rózga weselna będąca podstawowym, a w niektórych stronach - najważniejszym rekwizytem weselnym. We wschodniej części Sieradzkiego taką rózgę (jabłoneczkę) okrywano białym tiulowym welonem, podobnie jak pannę młodą. W obrzędowej sytuacji rózgę uznawano za symbol panny młodej i jej dziewictwa (ŁSE 7: 36; podob. ŁSE 8: 53).

$\mathrm{Na}$ Kujawach podczas uczty weselnej (przy tzw. dużym obiedzie) jabłonkę, tj. ustrojone drzewko lub kij obwieszony wstążkami i jabłkami, stawiano na stole przed siedzącą panną młodą (Krzyż Kuj: 72-73). W czasie oczepin jabłonką uderzano kilka razy o stół, śpiewając pieśń ilustrującą w sposób symboliczny życie panny młodej od narodzin do wieku dojrzałego:

A wiernie ja Panu Bogu słuzyła,
a kiedy ja jabłonecke sadziła.
Juźci moji jabłonecce rok mija,
juz sie moja jabłonecka ozwija.
Juźci moja jabłonecce dwie lecie,
juz na moij jabłonecce są kwiecie.
Juźci moja jabłonecka trzy lata,
juz na moij jabłonecce są jabka

(K 2 San: 54).

W innym wariancie mowa też o rozcinaniu jabłuszek z jabłoneczki:
A wiernie - my Panu Bogu służyli,
Przy dolinie jabłoneczkę sadzili,
Już tej naszej jabłoneczce minuta,
Już ta nasza jabłoneczka jak ruta,
Już tej naszej jabłoneczce godzina,
Już się nasza jabłoneczka przyina,
Już tej naszej jabłoneczce dwie lecie,
Już ta nasza jabłoneczka ma kwiecie,
Już tej naszej jabłoneczce trzy latka,

4 Akcentował je także Stefan Czarnowski (1956). 
Już ta nasza jabłoneczka ma jabłka,

Urwał ci jej pan młody dwanaście,

Odesłał je pannie młodej, staroście,

A pan młody na koniku wywija,

Szabeleczką jabłuseczka rozcina

(ESE 8: 52-53).

Moment przekazania staroście rózgi weselnej i jej wykupu przez pana młodego w sposób symboliczny wyraża akt wykluczenia młodej z grona druhen. Śpiewano wówczas:

A weźcie te jabłonecke z jabłkami,

a dejcie nom butelecke $\mathrm{z}$ trunkami.

A weźcie se jabłonecke, bo wasa,

a dejcie nom butelecke, bo nasa.

A z baryły, panie młody, z baryły,

żeby ci się syny, córy darzyły

(ŁSE 10: 145).

Oddajemy jabłoneczkę, bo wasza,

i prosimy buteleczkę, bo nasza.

Wyjedź, wyjedź z komóreczki,

napocnijże baryłecki i poczęstuj nas

(ŁSE 8: 53).

Jabłoneczka (rózga) weselna kojarzy się z zieloną różdżką, używaną w dawnej Polsce przy kupnie i sprzedaży.

Prawna wymowa rózgi jest aż nadto widoczna, ale nie ulega wątpliwości, że w przypadku przekazywania przez druhny jabłoneczki, moment ten również się zaznacza, co znajduje wyraz choćby w fakcie popicia, który wyraźnie przypomina litkup (Wieruszewska 1966: 54).

Z rózgi weselnej, wnoszonej do izby, druhny zdejmowały jabłka i obrzucały nimi nowożeńców (Bar Pil: 134). Sypiące się jabłka, „miały inicjować płodność i szczęście państwa młodych” (Kow Lek: 171). Na ziemi sądeckiej i rzeszowskiej jabłka zdejmowano z rozwidleń rózgi weselnej i rzucano na podołek panny młodej, aby „zapewnić jej płodność, lekkie porody, liczne, zdrowe potomstwo” (Ogrod Zwycz: 68). Podobną (płodnościową, miłosną) symbolikę do jabłek zdobiących rózgę miały w obrzędowości weselnej także jabłka i kwiaty jabłoni, którymi zdobiono korowaj/kołacz:

Wierzch korowaja był zdobiony figurkami wykonanymi z ciasta. Były to ptaki (gąski, kaczuszki, koguciki, bociany), księżyc, słońce, szyszki. Zdobiono go także kwiatami (róże, astry, asparagus, paprotka) wykonanymi często z papieru oraz cukierkami, 
owocami i zielonymi gałązkami kaliny i barwinku. W środku umieszczano gałązkę z jabłkami, tzw. różdżkę lub wiele zielonych gałązek (Etnl 1988 Bącz: 80)5.

Przed oczepinami korowaj wynoszono z komory, ustawiano na stole i śpiewano:

Oj, zawitajże śliczny darze,

oj, wyniesiony pod tragarze.

$\mathrm{Oj}$, z podola cię przywieziono,

oj, na stole cię posadzono.

$\mathrm{Oj}$, cukrem cię posypano,

oj, winem cię podlewano.

Oj, na skraju drobne ziele,

oj, na środku jabłek wiele

(Kot Las: $50-52$ ).

Symboliczne sensy kojarzone $\mathrm{z}$ atrybutami przedmiotowymi (rózgą weselną, korowajem) i obrzędowymi działaniami, fragmentaryczne i zachowane jedynie w pamięci osób starszych, można dziś wydobyć jeszcze z tekstów pieśni weselnych, w których mowa o jabłonce w sadeczku wiśniowym/malinowym czy jabłoneczce oberwanej z jabłek. Można je rozumieć jako znak, że panna młoda jest gotowa do zamążpójścia:

Oj, jabłonecka w sadku wiśniowym, siedzi Brygisia, płace za stołem.

O, wyńdzi, wyńdzi, Brygiś zza stoła, bo cię Brygisiu, tatula [matula, wujaszek, braciszek] woła.

A wyjść, wyjdę, siedzieć nie będę, tobie tatulu - robić nie będę.

[...]

O wyńdzi, wyńdzi, Brygiś zza stoła, bo cię Brygisiu, kochanie woła.

A wyjść, wyjdę, siedzieć nie będę,

Tobie Jasieńku - już robić będę

(K 23 Kal: 145-146).

Rośnie jabłónia w sadzie malinowym, siedzi pani młoda ji płacze za stołym.

Ach, ty panie młody, jej najmilejszy, weź białej chusteczki, "otrzyj jej "oczy.

Chociaż jej "otre, ona sie zapłacze,

przez ciebie, Janeczku, że swój wianek trace

(Krzyż Kuj: 108).

5 Sam korowaj (kołacz) posypany cukrem, ozdobiony zielem i jabłkami jest znakiem dostatku, urodzaju, sił witalnych, płodności i miłości (Etnl 1988 Bącz: 79-81). 
oraz symbol panny młodej, która pozbawiona rucianego wianka, tj. panieńskiej czystości, przechodzi do stanu mężatek:
Posła Marysia do kościoła, drobno stąpający,
wysła z kościoła, ale nie panieneczka.
Posła do sadeńka, oberwana jabłonecka, juze jej odpadła panieńska zabaweczka.
Posła do sadecku - oberwana wiśnia. juze jej odpadły penieńskie myśle.
Posła do sadecku - zerwany kwiateczek, oj, juze jej odpadł ruciany wianecek

(Plesz Międz: 70).

W tekstach kolęd życzących motyw jabłoni pod miesiączkiem i chmurką kojarzy się z ozdobą z opłatka zwaną światem, z zieloną gałęzią nazywaną nowym latkiem i połaźniczka (w zależności od regionu zwaną też podłazkiem, podłaźnikiem, jutka, jeglijka, sadem, rajskim sadem, bożym drzewkiem, wiecha) oraz bożonarodzeniową choinką (zob. Tomicka, Tomicki 1975: 76-77):

[Po wieczerzy wigilijnej] dziewczęta z opłatka robią „świat”, który na nitce wiesza się u tragarza. U spodu świata przymocowane bywa jabłko lub z braku tegoż cebula. Świat taki przechowuje się cały rok. Przeszłoroczny kruszy się do zboża przeznaczonego do siewu (Cisz Sławk: 29; ts. ZWAK: 215; K 5 Krak: 193).

Od Bożego Narodzenia [na Kurpiach] zawieszano dawniej w izbie gościnnej u pułapu (tuż nad stołem i wycinankami) małe drzewko - choinkę (sosenkę), czasem świerk, ubraną kolorowymi kwiatkami, jemiołą, jabłuszkami i orzechami. Nazywano to „nowym latkiem”, a wisiało do Trzech Króli lub nawet cały rok do nowego (PSL: 21).

W domach, gdzie są dziewczęta, ubierają na Boże Narodzenie gałązkę wiśniową, zwaną sadkiem, na której zawieszają orzechy, jabłka i którą przystrajają w łańcuszki z kolorowych papierów. Sadek ten wisi u środkowego stragarza pod Krzyżem, dopóki nie okolędują (Bieg Koleb: 491).

Winna (więc żywa, zielona) jabłoneczka z pieśni kolędniczej, w kontekście przywołanych atrybutów przedmiotowych - świata, nowego latka, połaźniczki i choinki - daje się interpretować w kategoriach drzewa kosmicznego, wyznaczającego trzy sfery świata. Kulisty kształt jabłka przypomina kształt kuli ziemskiej, a cztery jabłka na jabłoni - cztery strony świata:

Świeciuł ji miesiącek, świeciuł ji jaśniutko,

a pod tym miesiąckem chmurecka cerniutká,

a pod tą chmurecką wiśniowy sádecek,

a w tym ci sádecku winná jabłonecka,

na ty jabłunecce śtéry jabłusecka

(Święt Nadr: 86). 
Obraz jabłoneczki w środku podwóreczka z kolędy życzącej dla panny na tle sytuacji kolędowania o funkcji zalotnej daje się interpretować jako symboliczne przedstawienie panny gotowej do zamążpójścia:

W środku podwórecka stoji jabłonecka,

podaj, podaj, Maniu, rącke, moja kochanecka

(Bart Lub: 117).

Jabłoneczka zielona, na której są czerwone jabłka, wywołuje asocjacje z zakończeniem obrzędu, ze zrywaniem przez dziewczynę jabłek z choinki i obdarowywaniem nimi kawalera na znak sympatii:

Jak miała jabłko, pierwsze dała poczęstowała swojego narzeczonego, żeby spróbował jej daru, [...] zachęcić do miłości. [...] Jeśli przychodzili chłopcy do dziewczyny i mieli oberwać jabłuszko, to dziewczyna pozwalała tylko temu, który sie jej podobał. Jeżeli sie nie podobał, a chciał, to dziewczyna już nie pozwoliła tego jabłuszka zerwać (Smyk 2009: 187).

Tym samym w kolędowej pieśni komunikowane jest to, co wyraża gest i użyty przedmiot:

Rwała dziewczyna jabłka na Gody. Czerwone, ej, czerwone na jabłoneczce zielonej. Chusteczka na nij, kieby na pani. Jaś to dał, ej, Jaś to dał, bo ci ją wiernie szanował (Kot Zn: 297; war.: Kot Rzesz: 47, 377; Wisła 16: 704).

Dzielenie się (zwłaszcza czerwonym) jabłkiem z choinki i zjadanie go z ukochanym podczas obrzędu kolędowania traktowano jako usankcjonowanie miłości między kawalerem i panną oraz jako znak magicznej kreacji małżeństwa w nadchodzącym roku (Smyk 2009: 188). Dzielenie i krojenie jabłka, następnie spożywanie go przez pannę i kawalera przypomina również zaręczynowy zwyczaj zjadania przez narzeczonych połówek rozkrojonego jabłka:

[Zaręczyny. Po otrzymaniu błogosławieństwa młodzi] siedli za stołem, matka dziewczyny stawiała przed nimi talerz z jabłkiem, które przekroiwszy na dwie połowy, dawała młodym do spożycia (Kul Wiel 3: 136).

Symbolika wynikająca z użycia elementów kodu akcjonalnego i przedmiotowego znajduje potwierdzenie w licznych tekstach kolęd życzących z motywem jabłoneczki, z której dziewczyna zrywa złote lub czerwone jabłuszka. Jabłoneczka o złotych gałązeczkach, listeczkach, kwiateczkach i jabłuszkach jest w pieśni znakiem d ziewczyny war tościowej, która obdarowuje bliskich tym, co cenne; to, co najcenniejsze (samą siebie), oddaje ukochanemu:

Oj! Na gumieneczku rośnie jabłoneczka - hej, leluja!

Na tej jabłoneczce złote gałązeczki - hej leluja! 
$\mathrm{Na}$ tych gałązeczkach złociste listeczki - hej, leluja!

A między listkami złociste kwiateczki - hej, leluja!

A na tych kwiateczkach złociste jabłuszka - hej, leluja!

A któż je oberwał? Nadobna Anuśka - hej, leluja!

Komuż ona dała te złote jabłuszka - hej, leluja!

Jednoż dała swemu panu ojcu - hej, leluja!

Drugie ona dała swojej pani matce - hej, leluja!

Trzecie ona dała swemu panu bratu - hej, leluja!

Czwarte ona dała swojej pannie siostrze - hej, leluja!

Piąte ona dała temu, co kochała - hej, leluja!

Piąte ona dała, komu rozumiała - hej, leluja!

(K 44 Gór: 71; ts. Pau Gal: 3-4; Kot Rzesz: 192).

W kolędzie z motywem „wywyższenia ukochanego” dziewczyna zrywa czerwone jabłko z jabłoni, nie daje go ojcu, matce, bratu, siostrze, tylko ukochanemu:

U tej Marysi pod okienejkiem zielona,

zielona jabłoń, czerwone jabko zrodziła.

Tam popod gajem krasna Marysia chodziła,

oj, chodziła, czerwone jabłko nosiła.

Przyszed tam do niej tatusio to jej: Marysiu,

Marysiu duszko, daj mi jabłuszko czerwone.

Oj, nie dam, nie dam, sama jedno mam, oj, schowam,

schowam na Gody i na Świętego Szczepana.

[Kolejno przychodzą: matka, brat, siostra, dziewczyna nie daje im jabłuszka.]

Przyszed tam do niej najmilszy to jej: Marysiu,

Marysiu duszko, daj mi jabłuszko czerwone.

Oj, tobie dam, dam, choć jedno mam, oj, dam, dam,

rozkrój na dwoje, zjemy oboje w stodole!

(Bart PKL: 287-288).

Konwencja kolędy życzącej dopuszcza rozbudowywanie motywu jabłuszka i jabłoni o scenariusze nawet bardzo rozbudowane, np. panny, która przy jabłoni daje chłopcu chusteczkę jedwabną (symboliczny gest oddania samej siebie):

Na wprost okieneczka rośnie jabłoneczka.

Przyszedł do niej Janek, do jej okieneczka.

Ona mu, rada mu, wyszyła chusteczkę, dała mu.

Wyszyła chusteczkę białym jedwabiem, podała chusteczkę z komory okienkiem

(Kot Rzesz: 423-424).

W pieśniach zalotnych i miłosnych jabłoń (w sadzie, w ogrodzie, pod nią poduszka) wpisuje się w symboliczną przestrzeń miłości i spotkań kochanków: 
Tam w sadzie, tam w sadzie, tam pod jabłoneczką

często sobie bywo Jaś z swą kochanecką

(Stoin Żyw: 224)

Tam pod tą jabłonką, pod tą zieloną,

leży tam podusia stawką plecioną.

A na tej podusi córecka spała,

każdy wiecorecek na ni płakała

(Stoin Żyw: 307).

Jabłoneczka złotem pokrapiana jest zestawiana z urodą dziewczyny:

A w sadeczku jabłoneczka złotem pokrapiana,

widzi mi się, ma najmilejsza, coś mi malowana.

Choć ci ja się tobie widzę, ale nie każdemu.

Oj, tobieć to, mój najmilszy, tobieć to samemu

(K 40 MazP: 182).

Jabłonka zielona w planie symbolicznym jest przedstawieniem młodej dziewczyny:

Zielona jabłonka, w małym ogródku,

ani słychu, ni dychu, o mojim kochanku

(K 6 Krak: 476-477).

Jabłko czerwone i okragłe asocjuje z piersiami kobiecymi (por. jabłuszka jako potoczne nazwy piersi), z miłością fizyczną i obiektem pożądania:

Szła dziewczyna po rowie, po rowie,

gonili ją panowie, panowie.

Ty dziewcyno, co tu masz, co tu masz,

co fartuszkiem przykrywasz, przykrywasz.

Cy grusecki, cy jabka, cy jabka,

cy dla chłopców zabawka, zabawka

(K 42 Maz: 35-36).

Jabłuszko czerwone, wiszące na jabłoni, symbolizuje stałość uczuć:

Cyrwione jabłuszko wisi na jabłoni,

kocham cie, Marysiu, a ktoz mi zabroni

(Stoin Żyw: 145),

a takie, które spadło z drzewa - z miłością nieszczęśliwą i niespełnioną:

Czerwone jabłuszka obleciały w sadzie, ty, mój kochaneczku, nie stój mi na zdradzie

(K 44 Gór: 373). 
Jabłuszko słodkie, o którym mowa w pieśni, odbierane bywa jako znak miłości szczęśliwej, spełnionej:

Słodkie to jabłuszko, kto go pokosztuje.

Mają takie ciężkie serca, kto się zamiłuje.

I Jasio się w jednej pannie zamiłował.

Cztery lata do niej chodził, szczerze ją pokochał

(Kot Rzesz: 357),

i odwrotnie - jabłko kwaśne - jako brak uczuć ze strony ukochanego:

Nie każda jabłonka słodkie jabłka rodzi,

nie wierzaj ty chłopcu, dziewcze, choć on do cię chodzi.

Bo on do cię chodzi, a ino cię zwodzi,

a i co się wykręci, to o inszej myśli

(K 1 Pieś: 141).

Jabłko robaczywe wywołuje asocjacje $\mathrm{z}$ niestałym sercem chłopca:

Czerwone jabłuszko w środku robaczywe,

niejednego chłopca serce sprawiedliwe

(Płat Krak: 259-260).

Zrywanie czerwonych, słodziutkich jabłek w planie znaczeń naddanych bywa pojmowane jako spełnienie aktu miłosnego:

Koło mego "ogródecka

wyrosła mi jabłonecka.

Bielusieńko zakwitała,

cerwune jabłuszka miała.

A ktoz mi je będzie zrywoł,

kiej się na mnie Jaś pogniwoł?

Pogniwoł się, nie wim "o co,

ji przychodził nie wim po co.

Ji przychodził cału wiosne,

ji pytoł się cy jo rosne.

I przychodził całe lato,

dawałam mu buzi za to.

Ji przychodził cału jesień, i przychodził cału jesień,

dawałam mu japka w kieszeń

(TN 367B/59 Głusko 1980).

W ogrodzie, tj. w symbolicznej przestrzeni miłości, chłopiec prosi dziewczynę o to, by mógł jabłka zerwać, czyli ją posiąść:

Prosiłem ją w ogrodzie, w ogrodzie, w ogrodzie, żeby dała w swobodzie 
w ogrodzie,

w swobodzie, jabłuszko urwać.

Ale mi go nie dała, nie dała, nie dała, bo się mamy bojała, bojała, bojała,

w ogrodzie, w swobodzie jabłuszko urwać

(Płat Krak: 102).

Rozkrojenie zerwanego jabłka na dwoje i zjedzenie go (też gruszek) na łóżeczku, $w$ stodole na sianie, oznacza spełnienie miłości:

Nieszczęśliwe to łóżeczko, zjadłam na nim jabłuszeczko.

Matuleńce dobre było, córóleńce zyzne było.

A jak mi się siostra dowie, cóż ona mi na to powié?

Siostra by ci zazdrościła, bo by sama rada była.

O, jak mi się matka dowié, cóż ona mi na to powie?

Twoja matka wielka fuka, będzie rada, że ma wnuka.

(K 12 Poz: 174-175).

Nie rozcinaj mi jabłuszek, bo to grzech, bo to grzech, bo to Janku, bo to Janku będzie śmiech, będzie śmiech.

(ŁSE 10: 140).

Bladość dziewczyny po zjedzeniu jabłka jest oznaką utraty panieńskiej czystości:

Moja Kasiu, coś ty jadła,

cóżeś ty nam tak pobladła.

Jabłko jadłam, mamusiu, jabłko jadłam.

I my żeśmy jabłka jedli

i tak żeśmy nie pobledli.

Kwaśne było mamusiu, kwaśne było

(TN 211A/88 Bychawka 1977).

Po zjedzeniu w sadzie jabłka dziewczynę boli brzuszek:

Poszły panny do sadu, najadły się jabłuszek, wyszły do dom, kładą się, bo każdą bolał brzuszek

(K 22 Łęcz: 251).

W przemowach weselnych wygłaszanych podczas zapraszania na wesele biblijny motyw drzewa rajskiego, z którego Ewa zrywa jabłko, por.: 
Święta Ewa się odważyła, jabłko z jabłoni zerwała, pół do swoich ust doniosła i pół Adamowi dała.

Tak się potem zawstydzali, z drzewa liście obrywali i niemi się zasłaniali. Ach, fora, Adamie, fora! $\mathrm{Z}$ tak pięknego dwora!

(K 10 Poz: 297-299),

łączony bywa z tradycyjną symboliką pokusy, przekraczania zakazu i grzechu. Motyw ten ściśle współgra z motywacją zwyczaju zawieszania jabłek na choince:

I te jabłka się wieszało [...], żeby to była tradycja, że przez jabłko utraciliśmy wszystko, a Pan Jezus nas odrodził, jak się urodził (Smyk 2009: 186)

i zakazem ich zrywania do czasu rozbierania choinki:

Nie wolno u nas było zrywać jabłek, aż się chojinke rozbierało (Rzeczyca Ziemiańska, TW), dlatego, że to tak jak gdyby po prostu, znów od nowa pozwolić sobie sięgnąć po owoc z Raju (Smyk 2009: 185).

W tym samym gatunku jabłoń kojarzona jest z rajem jako miejscem szczęśliw ym, podarowanym Adamowi i Ewie (mężczyźnie i kobiecie) przez Boga:

Nase nogi nawiedzają wase progi, nie przyśli my tu z umysłu swego, tylko z rozkazu pana młodego, a pan młody z Adama świętego.

Święta Trójca zeznała,

ze para ludzi być miała.

Dał im Pan Bóg raj, a w raju jabłoni pilnować.

Jabłko orwała, Adamowi podała.

Tego jabka wszyscy (my) kośtowali, a takowe grzechy ku sobie wyznawali

(K 23 Kal: 160-162).

W oracjach weselnych latorośl z jabłoni o złotych liściach, znaleziona w ogrodzie przez człowieka obdarzonego łaską bożą to symbol panny pięknej i wartościowej, którą znalazł kawaler:

Był też to jedyn cłowiek [...]. I tak ón wszed do ogroda papierowego i natrafioł tam ogrodnika jego, który go zawiódł do jednej jabłoni pośród ogroda stojącej i siedem ostróg znającej, która złote liście miała i we wielkiej się piękności znajdowała. A gdy 
złote liście na tej jabłoni były, todź się też ślicne owoce na niej znajdowały. I tak ci do mie tą jedną latorośl z tej jabłoni dał, ino bych ją do śmierci przi sobie w ućciwości chował (Kur Opol: 44, 46-47, war. MAAE: 255).

W przemowie weselnej skierowanej do młodych przez drużbę - droga przed młodymi wybrukowana jabłkami jest znakiem ich płodności i sił witalnych:

Jest (dla was) droga naprawiona, zieloną rutą posypana, jabłkami wybrukowana, jodłowymi szpilkami wyłożona (Wisła 7: 458).

Koresponduje to z symboliką jabłek jako ozdób korowajowych, którymi obdarowywani są nowożeńcy.

W pieśniach sierocych jabłoń w lesie (podobnie jak grusza w polu/płocie i wiśnia $w$ sadzie) jest znakiem osamotnienia dziecka/dziewczyny:

Oj sama ja samuleńka jak jabłonka w lesie.

Jesce mi jeden ptasek nowinę przyniesie.

A sama ja samuleńka jak grusecka w polu.

Ni ma - ci mnie, ni ma - ci mnie pozałować komu.

A sama ja samuleńka jak wisienka w sadzie.

Jestem - ci ja, jestem ci ja ludziom na zawadzie

(K 27 Maz: 338).

Oj, samam ja, sama, jak jabłonka w lesie,

niejeden mi ptaszek nowinkę przyniesie.

Oj, samam ja, sama, jak kruszyczka w płocie.

Oj, nie wie nikt, nie wie o moim kłopocie.

Oj, samam ja sama, jak kruszyczka w polu,

a jeszcze mi ludzie nie dają pokoju

(K 40 MazP: 423-424).

W pieśniach żołnierskich jabłoń, która rośnie obok domu, ewokuje przestrzeń rodzinną, bliską, ukochaną, cichą i spokojną, za którą żołnierz tęskni, do której pragnie wrócić:

Gdzie ta chatka mchem porosła, co mnie wychowała, gdzie jabłonka ta wyniosła, co w ogródku stała.

Gdzie to źródło żywej wody z podziemi bijącej,

gdzie te moje lata młode jak kwiatki na łące.

Chatka w gruzy rozwalona, źródło bić przestało, jabłoń w próchno zamieniona, same łzy zostały

(Płat Krak: 670).

Oszalało słońce dziś w Bagdadzie

i gorący od pustyni wiatr,

a tam teraz cicho w moim sadzie

i jabłonie już obsypał kwiat! 
Mój maleńki sad, mój maleńki dom, pozostały za melodie snom!

Pełny cienia dom, pełny kwiatów sad, to $\mathrm{z}$ tysiąca drugiej bajki świat!

(Szew Niech: 755).

Błękitne niebo, pachnące łany zbóż, okryta kwieciem jabłoń stanowią pozytywny kontrast w stosunku do tego, co otacza żołnierza; okwiat, który spada z jabłoni to symboliczne przedstawienie przerwanego życia:

Maszerują chłopcy, maszerują, młodość z nimi idzie w krok.

Niebo błękitne, niebo pogodne, od łanów zapachy miodne, jabłonie strojne w kwiat. Maszerują chłopcy, maszerują, śmierć za nimi idzie w krok.

Hej, tam za górą słychać strzały, pada $\mathrm{z}$ jabłoni okwiat biały, krew rdzawi się u stóp

(Szew Niech: 67).

W efekcie jabłoń staje się miejscem pochówku żołnierza:

Wzięli go do wojska na rok go cały i w polu poległ, pod jabłoniami.

Ona od niego listów nie miała i z tej rozpaczy umrzeć musiała

(Świr Pieś: 374).

W bajkach złota jabłoń (jabłoń ze złotymi jabłkami) - której pilnują bracia przed złotym ptakiem / czarną świnią / kobietą, ale udaje się ją upilnować tylko najmłodszemu, uznawanemu za najgłupszego - jest symbolem skarbu i bogactwa (Krz PBL 1: nr 417, tam liczne warianty; podob. Etnl 1996 Bart: 281).

W bajkach o zbóju Madeju jabłoń wyrastająca z narzędzia zbrodni - pałki jabłoniowej / suchego patyka / laski lub kija jabłoniowego, którymi Madej zabił pierwszego człowieka / rodziców, jest symbolem życiodajnej siły i nieśmiertelności, a jabłka na takiej jabłoni są znakiem dusz ludzi zabitych (K 8 Krak: 122-123; podob. K 14 Poz: 200-201; Wój Klech: 135; liczne warianty zob. Gębała 2014: 73 i n.). Po spowiedzi Madeja jabłka znikają, spadają, unoszą się w górę lub zamieniają w gołębie.

W przysłowiach kompleks jabłoń i jabłko funkcjonuje na zupełnie innej zasadzie, służy przekazywaniu informacji o dziedziczeniu nawyków i cech (zwłaszcza negatywnych) między członkami rodziny: Niedaleko pada jabłko od jabłoni (NKPP I: 610-811, tamże liczne warianty, m.in.: Niedaleko od swego szczepu 
jabłko pada); Jaka jabłoń, takie jabłko (NKPP I: 812); Nie każda jabłonka słodkie jabłka rodzi (NKPP I: 812, tamże warianty: Kwaśna jabłoń nie rodzi słodkich jabłek; Kwaśny szczep słodkich jabłek nie obrodzi).

Przedstawione wyżej przykłady funkcjonowania obrazów JABŁKA i JABŁONI $\mathrm{w}$ tekstach polskiego folkloru pokazują ich wielorakie osadzenie $\mathrm{w}$ ramach polskiego ludowego kodu kulturowego, który poddany jest konwencjom gatunkowym.

Po pierwsze, w ramach gatunku symbole wykazują silną spójność. Tworzą układy kompleksowe, wzajemnie się warunkują i dopełniają. Przykładowo, w erotyku ludowym są to zespoły typu: jabłoń i ogród; jabłoń i sad; sad, jabłoń i poduszka; jabłoń i czerwone jabłuszka; jabłuszko i łóżeczko; jabłko i fartuszek; w bajce - ogród, jabłoń i ptak; w pieśni sierocej - jabłoń i las; w pieśni żołnierskiej: chata, ogródek, żywa woda, jabłonka; dom, sad, jabłoń; łany zbóż i kwitnąca jabłoń; w przemowach weselnych - raj, jabłko, jabłoń. W wariantach pieśni miłosnych, kolęd życzących i pieśni weselnych układy te podlegają ekwiwalencji. W erotykach ludowych jabłoń wymienia się z innymi drzewami żeńskimi - gruszą i wiśnią, a ogród, jako symboliczna przestrzeń miłości, zastępowany bywa sadem lub gajem. W kolędach życzących jabłoń rośnie albo w środku podwóreczka, albo przed domem, przed okienkiem, brama, sienią. W pieśniach weselnych sad wiśniowy bywa wymieniany z sadem malinowym. Zmiana, jaka dokonuje się w obrębie wariantów tekstu, nie pociąga jednak za sobą zmiany sensów symbolicznych.

Po drugie, symbole jabłka i jabłoni dobrze tłumaczą się na gruncie danych przyjęzykowych (wierzeń i praktyk), te same bowiem sensy - jak pokazała na innym materiale (kaliny, brony, drzewa itp.) Swietłana Tołstojowa (Tołstaja 2008) - mogą być wyrażane werbalnie, rytualnie bądź przedmiotowo. Przykładowo interpretację symboli z pieśni weselnej ułatwia odwołanie się do rekwizytu zwanego jabłoneczka, zdobienia korowaja jabłkami i kwiatami jabłoni oraz rytualnych działań w trakcie zaręczyn (krojenia jabłka i dzielenia połówkami narzeczonych). W interpretowaniu sensów symbolicznych zawartych w kolędach życzących pomocne są świąteczne rekwizyty przedmiotowe: nowe latko, podłaźniczka, choinka ozdobiona czerwonymi jabłuszkami, a także zachowania panny w trakcie obrzędowego kolędowania: zdejmowanie jabłka z choinki i obdarowywanie nim ukochanego.

Po trzecie, obrazy JABŁKA i JABŁONI służą także komunikowaniu wartości, które leżą u podłoża obrazu świata zawartego w danym gatunku tekstu, tj. - użyjmy raz jeszcze sformułowania J. Łotmana - wyrażaniu „treści kulturowo cenniejszych” niż sam obraz. Służą czemuś, co można określić mianem „symbolizowania aksjologicznego". W pieśniach miłosnych i zalotnych chodzi o wyrażanie szczęśliwej i spełnionej miłości, w kolędach życzących - gotowości do małżeństwa oraz ze względu na wykonywanie pieśni w noworocznym czasie - także o akcentowanie stabilnego kosmicznego porządku. W pieśniach weselnych symbole służą wyrażaniu płodności i witalności; w przemowach weselnych - pokusy i grzechu. W bajkach na poziomie znaczeń symbolicznych komunikowane są bogactwo, zdolność do regeneracji i od- 
nowy życia; w pieśniach sierocych w planie znaczeń naddanych eksponowane są poczucie bezpieczeństwa i opieka rodziców, w pieśniach żołnierskich - wartość domu rodzinnego i bycia z bliskimi; a w przysłowiach - są to prawdy ogólne traktowane jako przejaw „mądrości ludowej”.

Przykłady obrazów JABŁKA i JABŁONI przeniesione na inny grunt pokazują, że konwencje symboliczne poza obrębem określonej grupy społecznej tracą swoją wartość ${ }^{6}$, zakorzenione i zrozumiałe na gruncie polskiej kultury ludowej, przy użyciu poza naturalną wspólnotą okazują się nieczytelne i niezrozumiałe. Tak na przykład obrazy kwitnacej jabłoneczki czy zapylonej jabłoni znane z pieśni obrzędowych:

Koło mego ogródeczka zakwitała jabłoneczka,

bielusieńko zakwitała, czerwone jabłuszka miała

oraz

Siadła pszczółka na jabłoni i zapyliła kwiat, czemużeś mi moja miła zawiązała ten świat? -

bez odniesienia do właściwego kodu kulturowego (świata ludowych wyobrażeń i symboli) są niejasne i odbierane jedynie jako sygnał ludowości. Brak zakorzenienia w ludzkim doświadczeniu i osadzenia „w światopoglądowo-religijnym otoczeniu osób, które go używają" (por. Lurker 1994: 26) sprawia, że kwitnąca, bielusieńka jabłoneczka przestaje być kojarzona $\mathrm{z}$ dziewczyną gotową do zamążpójścia, jabłoń, na której wiszą czerwone jabłuszka - z panną dojrzałą do spełnienia roli kobiety, a zapylenie kwiatu jabłoni - z aktem miłosnym7. Obraz, który jest symboliczny, bo „myślowo ukonstytuowany"s na gruncie ludowym, po przeniesieniu na poziom innej kultury (ponadregionalnej, popularnej) bywa sprowadzany na poziom dosłowności, podlega więc istotnemu zubożeniu, brutalnej trywializacji treściowej i banalizacji aksjologicznej.

\section{Źródła}

BAR PIL: B. Baranowski, Życie codzienne wsi między Wartą a Pilicą w XIX wieku, Warszawa 1969.

BART LuB: J. Bartmiński, C. Hernas (red.), Kolędowanie na Lubelszczyźnie, „Literatura Ludowa” t. 25, 1986 (za rok 1981).

Bart PANLub: J. Bartmiński (red.), Polska pieśń i muzyka ludowa. Źródła i materiały, t. 4: Lubelskie, cz. 1: Pieśni i obrzędy doroczne, cz. 2: Pieśni i obrzędy rodzinne, cz. 3: Pieśni i teksty sytuacyjne, cz. 4: Pieśni powszechne, cz. 5: Pieśni stanowe i zawodowe, Lublin 2011.

6 Zwracał na to uwagę Stefan Czarnowski (1956: 212).

7 Tak np. w kontekście Święta kwitnącej jabłoni (zob. Adamowski 1994: 59).

8 Sformułowanie Jerzego Kmity (1987: 188). 
BART PKL: J. Bartmiński, Polskie kolędy ludowe. Antologia, Kraków 2002.

BART WĄż: J. Bartmiński, S. Niebrzegowska-Bartmińska, O. Kielak, Dlaczego wąż nie ma nóg? Zwierzęta w ludowych przekazach ustnych, Lublin 2015.

Bieg Koleb: H. Biegeleisen, U kolebki. Przed ołtarzem. Nad mogiła, Lwów 1929.

Cisz SŁAwK: S. Ciszewski, Lud rolniczo-górniczy z okolic Sławkowa w powiecie olkuskim, Kraków 1887.

ETNL 1988 BĄCZ: G. Bączkowska, Korowaj, „Etnolingwistyka” 1, 1988, s. 79-99.

ETNL 1996 BART: I. Bartmińska, J. Bartmiński, Bajki Józefy Pidek, „Etnolingwistyka” 8, 1996, s. $263-289$.

Folf ZAG: Polskie zagadki ludowe, wyb. i oprac. S. Folfasiński, Warszawa 1975.

K: O. Kolberg, Dzieła wszystkie:

K 1 Pieś: t. 1: Pieśni ludu polskiego, Kraków 1961 [wyd. fotoofsetowe z: Lud. Jego zwyczaje, sposób życia, mowa, podania, przysłowia, obrzędy, gusła, zabawy, pieśni, muzyka i tańce. Przedstawił... Serya I..., 1857].

K 2 SAN: t. 2: Sandomierskie, Kraków 1962 [wyd. fotoofset. z: Lud... Serya I [2]..., 1865]. K 5 KRAK: t. 5: Krakowskie, cz. 1, Kraków 1962 [wyd. fotoofset. z: Lud... Serya V..., 1871]. K 6 KRAK: t. 6: Krakowskie, cz. 2, Kraków 1963 [wyd. fotoofset. z: Lud... Serya VI..., 1873]. K 8 KraK: t. 8: Krakowskie, cz. 4, Warszawa - Kraków 1962 [wyd. fotoofset. z: Lud... Serya VIII..., 1875].

K 10 Poz: t. 10: W. Ks. Poznańskie, cz. 2, Kraków - Warszawa 1963 [wyd. fotoofset. z: Lud... Serya X..., 1876].

K 12 Poz: t. 12: W. Ks. Poznańskie, cz. 4, Kraków - Warszawa 1963 [wyd. fotoofset. z: Lud... Serya XII..., 1879].

K 14 Poz: t. 14: W. Ks. Poznańskie, cz. 6, Warszawa - Kraków 1962 [wyd. fotoofset. z: Lud... Serya XIV..., 1881].

K 22 ŁĘCZ: t. 22: Łęczyckie, Kraków - Warszawa 1964 [wyd. fotoofset. z: Lud... Serya XXII..., 1889].

K 23 KAL: t. 23: Kaliskie, Kraków - Warszawa 1964 [wyd. fotoofset. z: Lud... Serya XXIII..., 1890].

K 27 Maz: t. 27: Mazowsze, cz. 4, Warszawa - Kraków 1964 [wyd. fotoofset. z: Mazowsze. Obraz etnograficzny, t. 4: Mazowsze stare. Mazury. Kurpie, 1888].

K 40 MazP: t. 40: Mazury Pruskie, z rkps. oprac. W. Ogrodziński, D. Pawlak, red. D. Pawlak, Kraków - Warszawa 1966.

K 42 Maz: t. 42: Mazowsze, cz. 7, z rkps. oprac. A. Pawlak, M. Tarko, T. Zdancewicz, red. M. Tarko, Kraków - Warszawa 1970.

K 44 Gór: t. 44: Góry i Podgórze, cz. 1, z rkps. oprac. Z. Jasiewicz, D. Pawlak, red. E. Miller, Kraków - Warszawa 1968.

Кот Las: F. Kotula, Folklor słowny osobliwy Lasowiaków, Rzeszowiaków i Podgórzan, Lublin 1969.

Кот Rzesz: F. Kotula, Hej, leluja, czyli o wygasajacych starodawnych pieśniach kolędniczych $w$ Rzeszowskiem, Warszawa 1970.

Кот Zn: F. Kotula, Znaki przeszłości. Odchodzące ślady zatrzymać w pamięci, Warszawa 1976.

Kow LeK: P. Kowalski, Leksykon - znaki świata. Omen, przesąd, znaczenie, Warszawa Wrocław 1998.

Krz PBL: J. Krzyżanowski, Polska bajka ludowa w układzie systematycznym, wyd. 2 rozszerzone, t. 1, Wrocław 1962. 
Krzyż Kuj: B. Krzyżaniak, A. Pawlak, J. Lisakowski, Polska pieśń i muzyka ludowa. Źródła i materiaty, t. 1: Kujawy, cz. 1: Teksty, Warszawa 1974.

Kul Wiel: J. Burszta (red.), Kultura ludowa Wielkopolski, t. 3, Poznań 1967.

Kur Opol: Cz. Kurek, Tradycja i współczesność opolskich starostów weselnych, Opole 1978.

ŁSE: „Łódzkie Studia Etnograficzne”, t. 7: 1965, t. 8: 1966, t. 10: 1969, Łódź - Warszawa.

MAAE: „Materiały Antropologiczno-Archeologiczne i Etnograficzne wydawane staraniem Komisji Antropologicznej Akademii Umiejętności w Krakowie” V 1901.

NKPP: J. Krzyżanowski (red.), Nowa księga przysłów i wyrażeń przysłowiowych polskich, w oparciu o dzieło Samuela Adalberga oprac. zesp. red. pod kier. J. Krzyżanowskiego, t. I-IV, Warszawa 1969-1978.

Ogrod Zwycz: B. Ogrodowska, Zwyczaje, obrzędy i tradycje w Polsce, wyd. 2, Warszawa 2001.

Pau Gal: Ż. Pauli, Pieśni ludu polskiego w Galicji, red. H. Kapełuś, Wrocław 1973 [wyd. fototyp. z pierwodr. z 1838 r.].

Plesz MięDz: A. Pleszczyński, Bojarzy międzyrzeccy. Studium etnograficzne, Warszawa 1892.

PŁAт KRAK: Albośmy to jacy tacy. Zbiór pieśni Krakowiaków wschodnich i zachodnich, zebrał i oprac. P. Płatek, Kraków 1976.

PPiR: Pieśni polskie i ruskie ludu galicyjskiego z muzyka instrumentalna przez Karola Lipińskiego zebrał i wydał Wacław z Oleska, Lwów 1833.

PSL: „Polska Sztuka Ludowa” III, Warszawa 1964.

SToIn Żyw: Pieśni żywieckie, zebrał S.M. Stoiński, Kraków 1964.

Szew Niech: T. Szewera, Niech wiatr ja poniesie. Antologia pieśni z lat 1939-1945, wyd. 2. poszerzone, Łódź 1975.

ŚwiĘT NADR: J. Świętek, Lud nadrabski (od Gdowa po Bochnię). Obraz etnograficzny, Kraków 1893.

Świr Pieś: Z pieśnią i karabinem. Pieśni partyzanckie i okupacyjne z lat 1939-1945, wyboru dokonał S. Świrko, Warszawa 1971.

TN: Materiały terenowe z Pracowni „Archiwum Etnolingwistyczne” UMCS [po skrócie TN podano miejscowość i rok nagrania.]

WisŁA: „Wisła. Miesięcznik geograficzno-etnograficzny” t. 7, 1893, t. 16, 1902.

Wó Klech: Klechdy, starożytne podania i powieści ludu polskiego i Rusi, zebrał i spisat K.W. Wójcicki, wybór i oprac. R. Wojciechowski, wyd. 2, Warszawa 1974.

ZWAK: „Zbiór Wiadomości do Antropologii Krajowej wydawany staraniem Komisji Antropologicznej Akademii Umiejętności” X, Kraków 1886.

\section{Literatura}

AdAmowski J., 1994, Gatunek tekstu a znaczenie słowa (na materiale folkloru polskiego), „Etnolingwistyka” 6, s. 53-63.

AdAmowski J., BARTMiński J., 1988, Z problemów systematyki polskiej pieśni ludowej, [w:] T. Kłak (red.), Z problemów badania kultury ludowej, Katowice, s. 49-75.

BARTMIŃsKi J., 1974, Jaś koniki poił. Uwagi o stylu erotyku ludowego, „Teksty” nr 2, s. 11-24.

BARTMIŃsKi J., 1993, Ludowy styl artystyczny, [w:] idem (red.), Encyklopedia kultury polskiej XX wieku, t. 2: Współczesny język polski, Wrocław, s. 213-222. 
BARTMIŃski J., 2003, Miejsce wartości w językowym obrazie świata, [w:] idem (red.), Język w kręgu wartości. Studia semantyczne, Lublin, s. 59-86.

CzArnowski S., 1956, Warunki społeczne zmiany znaczenia symbolów literackich, [w:] idem, Dzieła, t. 1, Warszawa, s. 197-214.

Fromm E., 1972, Zapomniany język. Wstęp do rozumienia snów, baśni i mitów. Warszawa.

GĘBAŁA A., 2014, Językowo-kulturowy obraz JABŁONI $i$ JABŁKA w języku potocznym i polskiej kulturze ludowej. Analiza etnolingwistyczna, Uniwersytet Marii Curie-Skłodowskiej, Instytut Filologii Polskiej, praca magisterska, mszps.

GręBECKA Z., 2006, Słowo magiczne poddane technologii. Magia ludowa w praktykach postsowieckiej kultury popularnej, Kraków.

ISJP: M. Bańko (red.), Inny słownik języka polskiego, Warszawa 2000.

KмIтA J., 1987, Symbolizowanie jako relacja aksjologiczna oraz jako relacja semantyczna, [w:] T. Kostyrko (red.), Symbol i poznanie. W poszukiwaniu koncepcji integrującej, Poznań, s. $188-198$.

KrzeszowsKi T., 1994, Parametr aksjologiczny w przedpojęciowych schematach wyobrażeniowych, „Etnolingwistyka” 6, s. 29-51.

LURKer M., 1994, Przesłanie symboli w mitach, kulturach i religiach, Kraków.

Łotman J., 1988, Symbol w systemie kultury, „Polska Sztuka Ludowa. Konteksty” nr 3, S. $151-154$.

Mayenowa M.R., 1974, Poetyka teoretyczna, Wrocław.

NiebrzegowsKa-BARTMiŃsKa S., 2013, Ustalanie znaczeń symbolicznych $w$ słowniku etnolingwistycznym, „LingVaria” nr 1 (15), s. 127-144, [on-line:] http://dx.doi.org/10.12797/ LV.08.2013.15.12.

NiebrzegowsKa-BARtmińska S., 2015, Znaczenia symboliczne a wartości, [w:] J. Adamowski, M. Wójcicka (red.), Tradycja dla współczesności. Ciagłość i zmiana, t. 8: Wartości w języku i kulturze, Lublin, s. 47-64.

РотевniA A.А., 1883-1887, [= Потебня А.А.], Объяснения малорусских и сродных народных песен, t. 2, Варшава.

РотевniA А.А., 2007, [= Потебня А.А.], Символ и миб в народной культуре, „Разыскивания в области филологии, истории и традиционной культуры”, Москва.

Pвовок K., 2014, Gorzała lipka i jawor - lubelskie erotyki ludowe, [w:] J. Bartmiński, B. Maksymiuk-Pacek (red.), Lubelska pieśń ludowa na tle porównawczym, Lublin, s. 169-192.

Sмүк K., 2009, Choinka w kulturze polskiej. Symbolika drzewka i ozdób, Kraków.

Toџstaja S.M., 2008, [= Толстая C.M.], Пространство слова. Лексическая семантика в общеславянской перспективе, Москва.

ТоєSтол N.I., 1995, [= Толстой Н.И.], Язык и народная культура. Очерки по славянской мифологии и этнолингвистике, Москва.

Tоміска J., Томіскі R., 1975, Drzewo życia. Ludowa wizja świata i człowieka, Warszawa.

WieruszewsKa M., 1966, Obrzędy recepcyjne wieku dojrzałego w Bełchatowskiem, „Łódzkie Studia Etnograficzne”, t. 8, s. 25-82. 


\section{Genre conditioning of symbolic meanings Summary}

Folklore texts operate on two levels: inside the folk culture in combination with traditional beliefs and customs, and within the national culture as a point of reference and source of inspiration for writers and poets. Individual words also function on those two levels, as they can be understood 'the literary way' or 'the folk way'. The paper presents two units of the vocabulary of the national language (jabłon' 'apple tree' and jabłko 'apple') which have fixed base meanings but which also accommodate additional senses on a higher semantic level and thus become the signifiant for a new sign. In folklore texts, depending on the genre, the images of APPLE TREE and APPLE accept the symbolic senses of happy and fulfilled love (in love and courting songs), fertility and vitality (in wedding songs), of readiness for marriage and the stable, cosmic order (in wishing carols), of temptation and sin (in nativity plays), richness and ability to regenerate and renew life (in fairy tales), of the sense of security and parental care (in orphan songs), of the value of family home and proximity to the loved ones (in soldiers' songs). These symbols can be explained using extralinguistic data (beliefs and customs) as the same senses can be expressed through words, rituals, or objects. The analysis reveals that the images of APPLE TREE and APPLE serve to communicate values underlying the image of the world contained within the specific genre. The same images, transplanted to a different domain, outside of their particular social group, lose their value, become illegible, incomprehensible, and are viewed as merely a signal of folksiness. 